\title{
Class 1 deverbal and non-deverbal nouns in Shona: A comparative analysis
}

\author{
Calisto Mudzingwa \\ Research Fellow, Department of African Languages, University of South Africa, South Africa \\ E-mail: calistomudzingwa1@gmail.com
}

Maxwell Kadenge

Department of Linguistics, School of Literature, Language and Media, University of the Witwatersrand, Johannesburg, South Africa

E-mail: maxwell.kadenge@wits.ac.za

\begin{abstract}
The main aim of this article is to present a comparative analysis of some synchronic morphological properties of Shona class 1 non-deverbal and deverbal nouns. On the surface, these nouns, like most other Bantu nouns, look superficially similar; they comprise a noun class prefix and a noun stem. However, this belies a huge diversity amongst these nouns. We demonstrate that class 1 non-deverbal and deverbal nouns display the following differences: first, the stems of non-deverbal nouns are monomorphemic whereas those of deverbal nouns are minimally bimorphemic and are derived from verb roots. Secondly, the boundaries between the class prefix and the nominal stem behave differently. To this end, we use vowel hiatus resolution as a diagnostic tool to demonstrate the differences. Third, in forming diminutives of non-deverbal nouns, there is substitution of prefixes whereas for the deverbal nouns there is stacking of prefixes. We demonstrate that deverbal and non-deverbal nouns behave differently with respect to their phonology and derivational properties. We conclude that nouns in class 1 are not uniform and a theory of noun classes needs to be rich enough to account for the diversity. This research contributes towards the description and analysis of Shona nominal morphology in particular, and Bantu Linguistics in general.
\end{abstract}

Keywords: deverbal, non-deverbal, noun, substitution, stacking, morphology

\section{Introduction}

One of the principal identifying characteristics of the Bantu language family is the system used to classify nouns - the noun class system (cf. Bleek 1862, Meinhof 1932, Guthrie 1948). Shona, a southern Bantu language spoken mainly in Zimbabwe, has an interesting noun class system comprising 21 noun classes (Fortune 1955, 1984). Shona nouns look superficially similar; they comprise a noun class prefix and a noun stem (Fortune 1955, 1984). This, however, belies the 
huge diversity in structure, behaviour and distribution amongst the nouns. As an illustration, Shona nouns that fall into class 1 have the following morphological structure (cf. Fortune 1955, 1984; Mkanganwi 1995):

$$
\text { noun class prefix }+ \text { noun stem }
$$

Fortune (1955) goes further and observes that Shona nouns in class 1 share the following semantic and syntactic properties:

- $\quad$ are [normal] specimens of persons of various kinds and conditions;

- $\quad$ are members of tribes and peoples, and

- $\quad$ are either agents or patients of verbal action.

The few morphological and semantic similarities shared by nouns in class 1 mask the significant morphological and morphophonological differences between the non-deverbal and deverbal nouns that fall into this class. As an illustration, all non-deverbal nouns from class 1 can fall into class 5 (the augmentative class) to denote size. The initial consonant of the stem is voiced, as shown in examples (2) through (4). The diacritic [..] is used to capture breathy voicing.

\section{Class 1}

(2)

$$
\begin{aligned}
& \text { mu-komana } \\
& \text { CL1.SG-boy } \\
& \text { 'boy' }
\end{aligned}
$$

$$
\begin{aligned}
& \text { mu-sikana } \\
& \text { CL.SG-girl } \\
& \text { 'girl' }
\end{aligned}
$$

$$
\begin{aligned}
& \text { mu-kono } \\
& \text { CL1.SG-male } \\
& \text { 'male' }
\end{aligned}
$$

\section{Class 5}

$$
\begin{aligned}
& \text { gomana } \\
& \text { C̈L5.SG-boy } \\
& \text { 'big boy' } \\
& \text { džikana } \\
& \text { CL5.SG-girl } \\
& \text { 'big girl' } \\
& \text { gono } \\
& \text { C̈L5.SG-male }
\end{aligned}
$$

'big male'

In contrast, deverbal nouns in class 1 fail to undergo a similar process; they cannot fall into class 5 to denote size. Instead, they fall into class 21 where they retain the class 1 prefix, resulting in the stacking of class prefixes. This is illustrated in examples (5) through (7):

\section{Class 1}

(5)

$$
\begin{aligned}
& \text { mu-cheri } \\
& \text { CL1-drinker } \\
& \text { 'drinker' } \\
& \text { mu-tadzi } \\
& \text { CL1-sinner } \\
& \text { 'sinner' }
\end{aligned}
$$

(6) mu-tadzi

\section{Class 5}

$*_{\text {jeri }}{ }^{1}$

* ḍadzi

\section{Class 21}

zi-mu-cheri CL21-CL1-drinker 'heavy drinker'

zi-mu-tadzi CL21-CL1-sinner 'sinful person'

\footnotetext{
${ }^{1}$ Here [j] represents the breathy voiced palatal affricate.
} 


\author{
mu-tendi \\ CL1-believer \\ 'believer'
}

\author{
$* d e^{n} \mathrm{di}$ \\ zi-mu-te ${ }^{\text {ndi }}$ \\ CL21-CL1-believer \\ 'huge believer'
}

For the deverbal nouns that fall into class 1, their morphological behaviour and distribution is radically different from the non-deverbal nouns that fall into this class. If we compare the structure, behaviour and distribution of the deverbal nouns vis-à-vis non-deverbal nouns ("inherent nouns") of class 1, there are significant differences. We demonstrate these differences by examining plural formation, diminutives and augmentatives. Furthermore, there is evidence that stems of deverbal nouns are not as "nouny" as stems of non-deverbal nouns. Following Mudzingwa (2010) and Mudzingwa and Kadenge (2011), we use hiatus resolution strategies as a diagnostic tool to establish the differences between the boundaries of deverbal and non-deverbal nouns that fall in class 1. Mindful of such observations, this article compares the morphological and morphophonological properties of non-deverbal and deverbal nouns of class 1 , in an attempt to obtain a deeper understanding of the Shona nominal system in particular, and Bantu languages in general.

\title{
2. Brief overview of the morphology of the Shona noun system
}

In this section, we briefly discuss the morphology of the Shona noun class system as background to the analysis. Shona has a relatively more elaborate noun class system compared to other Bantu languages. It has 21 noun classes (see, for example, Fortune 1955, 1984; Mkanganwi 1995; Mudzingwa 2010).

\subsection{The noun class prefix}

Shona, like other Bantu languages, has class prefixes determined by the class to which a particular noun belongs (Bleek 1862, Meinhof 1932, Guthrie 1948). Noun class prefixes come in three prosodic shapes, namely $\mathrm{CV}, \mathrm{V}$ and $/ Ø /$ (zero prefix). The typical prosodic shape of noun class prefixes in Shona comprises a consonant and a vowel (CV). Likewise, Hyman (2005:17) observes that CV is the canonical prosodic shape for Bantu noun class prefixes. In Shona, all noun class prefixes that have phonological content are $\mathrm{CV}$, except for class 14 which is a $\mathrm{V}$.

All the noun class prefixes encode gender, number and semantic information. The prefixes of classes 1a and 5 are listed as /Ø/ (zero prefix). Fortune $(1955,1984)$ lists the prefix in classes 9 and 10 as $/ \mathrm{N}-/$, a non-syllabic nasal consonant. This, however, is not true of synchronic Shona morphology. We consider the prefixes of classes 9 and 10 as /Ø/ for two reasons: first, these noun class prefixes lack phonological content just like those of classes 1a and 5. Second, and perhaps more important, some of the nouns in classes 9 and 10, such as shumba 'lion' and shinda 'wool', do not even begin with a non-syllabic nasal / $\mathrm{N}-/$ but are in this class on the basis of concordial agreement. The non-syllabic nasal, which is a class prefix in other Bantu languages, may have been active in diachronic Shona. Consequently, the members of classes 1a, 5, 9 and 10 are marked by the significant absence of an overt prefix. In spite of the absence of a non-syllabic prefix, the zero morpheme /Ø/ fulfils the same classifying function syntactically as the presence of an overt prefix. 
The noun class prefixes are numbered according to Meinhof's system of enumeration in UrBantu (Fortune 1955:53) as demonstrated below.

\section{Class}

Class $1 \mathrm{SG}$

Class 1a SG

Class $2 \mathrm{PL}$

Class $3 \mathrm{SG}$

Class 4PL

Class $5 \mathrm{SG}$

Class 6PL

Class 7 SG.DIMIN

Class 8 PL.DiMIN

Class 9SG

Class $10 \mathrm{PL}$

Class 11 Sg.DimIN

Class 12 SG.DimIN

Class 13 PL.DIMIN

Class 14

Class 15

Class 16 LOC

Class 17 LOC

Class 18 LOC

Class 19 DIMIN

Class 21 AUG

\section{Noun Prefix (NP)}

mù-

Ø-

vá-

mù-

mì-

$\varnothing-$

mà-

tî-

zì-

$\varnothing$ -

$\varnothing-$

rù-

kà-

tù-

ù-

kù-

pù-

kù-

mù-

sì-

zì-

$\begin{array}{ll}\text { Example } & \text { Gloss } \\ \text { mù-kómáná } & \text { 'boy' } \\ \text { Ø-6àbá } & \text { 'father' } \\ \text { vá-kómáná } & \text { 'boys' } \\ \text { mù-sáná } & \text { 'back' } \\ \text { mì-sáná } & \text { 'backs' } \\ \text { Ø-bàdzá } & \text { 'hoe' } \\ \text { mà-pàdzá } & \text { 'hoes' } \\ \text { yî-só } & \text { 'razor' } \\ \text { zì-só } & \text { 'razors' } \\ \text { Ø-nóká } & \text { 'snake' } \\ \text { Ø--nóká } & \text { 'snakes' } \\ \text { rù-kómáná } & \text { 'sickly boy' } \\ \text { kà-mù-sáná } & \text { 'small back' } \\ \text { tù-kómáná } & \text { 'small boys' } \\ \text { ù--fí } & \text { 'honey' } \\ \text { kù-tárá } & \text { 'to underline' } \\ \text { pà-mù-sáná } & \text { 'on the back' } \\ \text { kù-mù-sáná } & \text { 'at the back' } \\ \text { mù-mù-sáná } & \text { 'in the back' } \\ \text { sì-mù-kómáná } & \text { 'boy' } \\ \text { zì-mù-fá } & \text { 'big home' }\end{array}$

Shona noun class prefixes often enter into pair-wise contrasts. The most common pairing is the singular-plural contrast where class 1 pairs with class 2,3 with 4,5 with 6,7 with 8 , and 9 with 10. Nouns in class 14 are usually abstract nouns; when they are plural, they generally fall into class 6. Class 15 is unique as it comprises the infinitives (also called "verbal nouns"). Classes $7,8,11,12,13$ and 19 are diminutives. Class 21 is augmentative. Classes 16, 17 and 18 are locatives. With the exception of the infinitives, diminutives, augmentatives and locatives, which allow for more than a single noun class (i.e. stacking of prefixes), all the other nouns are simple and conform to the constructional pattern given in (1).

\subsection{The noun stem}

Noun stems may be primary or secondary. Secondary stems are derived from other parts of speech, such as verbs, adjectives and ideophones, while primary stems are those that show no sign of origin from another word class category. Typical Shona examples of primary stems are -nhu in munhu ('person') and -ti in muti ('tree'). In contrast, Fortune (1955:48) defines a "root" as "the irreducible element of a word, the primitive radical form without the prefix, suffix, or other inflection and not admitting analysis". If we consider that in Shona, and other Bantu languages, what is called a "stem" meets Fortune's definition of a "root", it seems more insightful to say that what are called noun stems in Bantu are in fact roots that are co-extensive with stems. This explains why Mugane (1997) refers to underived nouns as "root nouns". He tries to capture the fact that the root is co-extensive with the stem. The difference between the primary stem (or underived stem) and the derived stem is that the former is monomorphemic 
whilst the latter is at least bimorphemic. Class 1 nouns have the structure in (1), repeated here in (8) for clarity and convenience:

$$
\text { noun class prefix }+ \text { noun stem }
$$

This can be represented as a tree diagram, as shown in Figure 1.

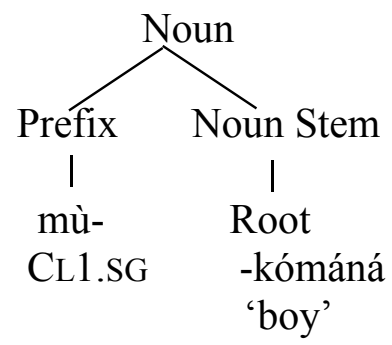

Figure 1. The morphological structure of a noun

Reading Figure 1 from the top down, a noun comprises the class prefix /mù-/ and the root /kómáná/ that is co-extensive with a noun stem. Commenting on the structure of the nouns in Shona, Fortune (1955:50) says that "in general, both elements, that is, the prefix and the stem, are necessary to constitute the complete noun". The prefix is important for classificatory purposes. Nouns are divided into classes on the basis of their noun class prefixes. The following section compares the structures of non-deverbal and deverbal nouns in Shona.

\section{Non-deverbal and deverbal nouns: A comparison}

\subsection{The non-deverbal noun}

A non-deverbal noun stem is monomorphemic, as shown in examples (9) to (11) below.
(9) /mù-kómánál
[mùkómáná]
CL1.SG-boy
'boy'
(10)
/mù-síkánál
CL1.SG-girl 'girl'
[mùsíkáná]
(11) /mù-kádzíl
CL1.SG-woman
'woman'
[mùkádzí]

The non-deverbal noun comprises a monomorphemic noun stem and a class prefix. Strictly speaking, the non-deverbal noun is made up of a noun root, which is co-extensive with a noun stem, to which a noun class prefix is attached. Figure 2 demonstrates a root which is coextensive with a stem. 


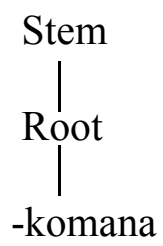

Figure 2. Non-deverbal noun root $=$ noun stem

A noun class prefix is attached to the above stem to form a noun, as illustrated in Figure 3.

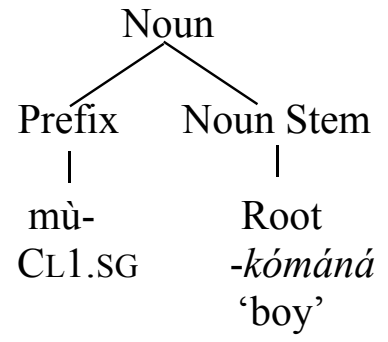

Figure 3. A non-deverbal noun

As seen in Figure 3, underived or non-deverbal nouns have a very simple structure - they are made up of a noun class prefix /mù-/ and a monomorphemic stem /-kómáná/. As will be illustrated in the next section, deverbal nouns have a more complex structure in that the deverbal noun stem is at least bimorphemic.

\subsection{Deverbal nouns}

This section examines the morphology of deverbal nouns, beginning with the structure of the verb stem which forms the core of nouns of this type. This will aid in providing a deeper understanding of deverbal noun stems and will help us to understand the structural differences between deverbal nouns and non-deverbal nouns, particularly with regard to the stem.

\subsubsection{The verb structure}

We adopt the canonical morphosyntactic structure of the Bantu verb proposed by scholars such as Keach (1986), Mutaka and Hyman (1990), Myers (1990), Hyman (1993, 2005), Downing (1998, 2006) and Ngunga (2000), amongst others. This structure consists of the following morphosyntactic constituents:

- $\quad$ Derivational Stem² ${ }^{2}$ DStem);

- $\quad$ Inflected Verb Stem (IVStem);

- MacroStem, and

- $\quad$ PreStem or Inflectional Stem

\footnotetext{
${ }^{2}$ We make no distinctions between the Minimal Stem and the Extended Derived Stems since such distinctions are not crucial in this article (see, for example, Downing 1998, 2005 and Ngunga 2000 for a detailed discussion).
} 


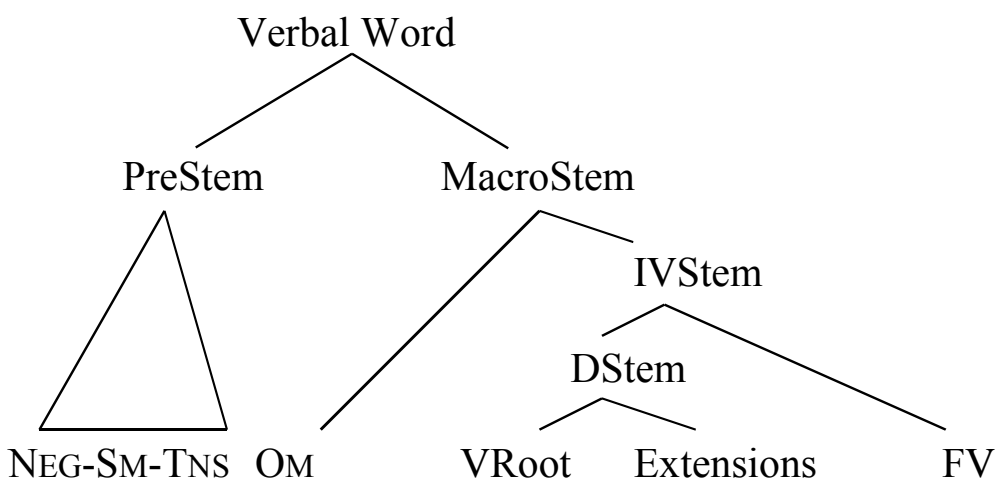

Figure 4. The morphology of the Bantu verb structure

Scholars of Bantu languages, such as Meeussen (1967), Keach (1986), Myers (1990), Hyman (1993), and Downing (1998, 2005, 2006), amongst others, have provided both phonological and morphological evidence for the various constituents of the verb illustrated in Figure 4 above. For the purposes of this article, we will briefly discuss the DStem and the IVStem.

\subsubsection{Verb Root}

The VRoot has three distinct properties. Firstly, it is syllabically incomplete and always ends in a consonant (C-final). Secondly, it takes the form of a bound morpheme which accepts morphemes before and after it. Finally, the VRoot is monotonic, i.e. it carries a single tone (either high $(\mathrm{H})$ or low $(\mathrm{L})$ ).

Shona VRoots have the following prosodic shapes:

$\begin{array}{lll}\text { Prosodic shape } & \text { Example } & \text { Gloss } \\ \mathrm{C} & \text { /p'-/ } & \text { 'give' } \\ \mathrm{VC} & \text { /ón-/ } & \text { 'see' } \\ \mathrm{CVC} & \text { /gár-/ } & \text { 'sit' } \\ \mathrm{CVCVC} & \text { /tónór-/ } & \text { 'bribe' } \\ \text { CVCVCVC } & \text { /tónó } & \\ & & \end{array}$

\subsubsection{Derivational Stem}

The DStem also has three distinguishing features. As with the VRoot properties, the DStem is monotonic as well as C-final. Its final feature is that it is a domain for vowel harmony.

The structure of the DStem is illustrated in Figure 5 (cf. Myers 1990, Downing 2000) . $^{3}$

\footnotetext{
${ }^{3}$ Myers (1990) and Downing (2000) argue that the VRoot is the Minimal Stem, and the VRoot plus the extensional suffixes comprise the Extended Derived Stem.
} 


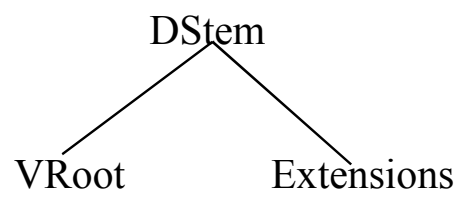

Figure 5. Derivational Stem

Reading Figure 5 from top to bottom, the DStem comprises a VRoot and verb extensions. The verbal extensional suffixes come immediately after the VRoot. Furthermore, these suffixes do not have an inherent tone and always assume the tone pattern of the VRoot. The Shona verbal extensions have different prosodic shapes, namely VC, C and VCVC.

\begin{tabular}{lllll} 
Extension & \multicolumn{2}{l}{ Prosodic shape } & Example & Gloss \\
intensive & VC & /-is- -es-/ & 6át-ís- & 'hold tightly' \\
potential & VC & /-ik- ek-/ & 6át-ík- & 'be able to be held' \\
reciprocal & VC & /-an-/ & 6át-án- & 'hold each other' \\
contactive & VC & /-at-/ & nàm-àt- & 'adhere to' \\
associative & VC & /-an-/ & gón-án- & 'curl' \\
applied & VC & /-ir- -er/ & Ëát-ír- & 'hold for' \\
causative & VC & /-is- -es-/ & rúm-ís- & 'cause to bite' \\
repetitive & VCVC & /-urur $\sim$ oror-/ kàr-urùr- & 'resow' \\
perfective & VCVC & /-irir -erer-/ & sèk-èrèr- & 'laugh on and on' \\
passive & C & /-w-/ & tèm-w- & 'be stoned'
\end{tabular}

These extensions are productive in Shona except the contactive -at- which, like in most Bantu languages, has been fossilised (see Jefferies 2000). In Shona, VC is the most prevalent prosodic shape for the extensions. Likewise, Hyman (2005:17) observes that the canonical shape of the verbal extension in Bantu is VC. In fact, the VCVC verbal extensions seem to have undergone reduplication. Similar to the VRoot, the verbal extensions are C-final.

\subsubsection{Inflected Verb Stem}

The IVStem comprises the DStem and the final vowel (FV), the latter also called the "Inflectional Final Suffix" (IFS; cf. Downing 2000). Figure 6 shows the correspondence relations between the IVStem and the prosodic constituent. 


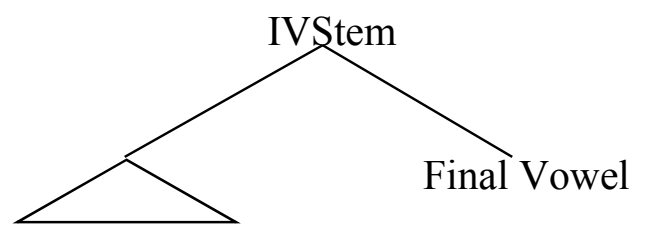

DStem

Figure 6. Inflected Verb Stem

As previously mentioned, the IVStem comprises the DStem (VRoot plus extensions - see Figure 5), and the FV. The IVStem corresponds to a prosodic stem which can be co-extensive with a prosodic word. The generalisations about the FV are as follows:

- $\quad$ when the FV is /a/, it satisfies the prosodic constraint that all Shona syllables must be open;

- $\quad$ when the FV is /e/ or /i/, in addition to satisfying this prosodic constraint, it also provides morphological information, and

- $\quad$ the FV assumes the tone of the root.

The FV has received very little attention in previous studies of Shona morphology and morphophonology, and when it does, it is often explained away as a default FV. There is little attempt to address its status, whether it is phonological, syntactic or a combination of these. Following Mkanganwi (2002), we consider the FV to serve a dual purpose - it has phonological and morphosyntactic functions. Mkanganwi (2002:184) states:

The final vowel seems to have a dual morphological and phonological function. On the one hand, it is analyzable as a distinct morphological element quite separate from the verb [...] On the other hand, it does not seem to have an evident meaning or grammatical function. Its apparently purely mechanical role seems to be purely phonological. However, it seems to perform a distinct derivational role [too!].

In its phonological role, the FV is needed so that the final consonant of the stem is properly syllabified. The DStem is C-final, yet Shona only allows open syllables (see, for example, Fortune 1955, Mkanganwi 1995, Mudzingwa 2010, Mudzingwa and Kadenge 2013). Joining the DStem and the FV provides the final consonant of the DStem with a vowel, resulting in a well-formed (CV) final syllable. In Shona, like in most other Bantu languages, the FV is the vowel /a/. Like other verbal suffixes, it does not have an inherent tone and it assumes the tone of the root to which it is attached. This means that the IVStem has a single tone pattern. In instances where the root comprises a consonant, there is a floating tone which docks onto the FV. In (12), (13) and (14), there is a floating $\mathrm{H}$ tone and in (15), (16) and (17) a L tone.
$/ \mathrm{p}^{\prime}-\mathrm{a} /$
give-Fv
[pá]
'give!' 

(13) /gár-a/ sit-FV
'sit!'
[g̣árá]
(14) /tónór-a/
bribe-Fv
'bribe!'
[tónórá]
(15) $/ \mathrm{g}^{\mathrm{w}}-\mathrm{a} /$
fight-Fv
[g $g^{w}$ à]
'fight!'
(16) /6ùr-a/
remove-Fv
[bùrà]
'remove (object) from fire!'
(17) /dürùr-a/
pour out-FV
'pour out liquid or grain!'
[dùrùrà]

In this context, the FV does not play any morphological or morphosyntactic role other than ensuring that the phonotactics of the language are satisfied.

In the examples in (18) and (19) below, the FV plays a dual role: it satisfies the phonotactics of the language and also plays a grammatical function. In (18), the FV marks negation and in (19) marks the subjunctive.
/mù-kómáná hà-á-fámb-i/
CL1.SG-boy NeG-3SG.SuBJ-walk-Fv(NeG)
[mùkómáná hnànăáfámbí]
'the boy does not walk'
(19) /ndí-tór-e hièrè/
1SG.SUBJ-take-FV INTERROG.
'should I take it?'

\subsubsection{Structure of deverbal nouns}

The core of a deverbal noun is the DStem (cf. Figure 6). To the right of the DStem is a nominalising FV and to the left is a noun class prefix. Example (20) includes a verb and examples (21) to (23) are the deverbal nouns derived from this verb.

(20)
$/$ tén $^{\mathrm{g}} \mathrm{g}-\mathrm{a} /$
buy-Fv
[téngà]
'buy!' 
(21)

/mù- té ${ }^{\mathrm{p}} \mathrm{g}-\mathrm{i} /$
CL1.SG-buy-NON
'buyer'

(22) /mù- té ${ }^{\mathrm{p} g} \mathrm{~g}$-és-ì/

CL1.SG-buy-CAUS-NON

'traitor'

(23) /mù- tég g-ò/

CL3.SG-buy-NON

'price' [mùténgí]

[mùténgésí]

[mùtég gó]

The deverbal nouns in (21), (22) and (23) display properties unique to nouns. First, these nouns have a class prefix. Second, the quality of the FV is different from that found in the citation forms of the verbs, the latter which is always /a/. Third, the tone of the FV is different from that of the verb stem. In the above examples, the FV has a low tone whereas the derived verb stem (in italics) is high toned. Recall that within verbs the FV assumes the tone of the verb stem. Based on the class prefix, the quality of the FV and tone, we argue that the forms in (21) to (23) are deverbal nouns. The structures of the deverbal nouns are given in Figures 7 and 8.

Figure 7 below provides the structure of the deverbal noun without verbal extensions.

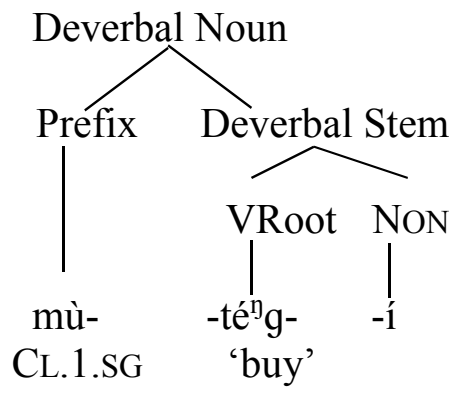

Figure 7. Deverbal noun without verbal extensions

Here, the deverbal noun is made up of the prefix /mù-/ and a deverbal stem, the latter being composed of a VRoot and a nominalising FV. When the "nominaliser" [i] is added to the VRoot, the VRoot becomes a deverbal noun stem. However, the nominalisation only becomes complete with the addition of the noun class prefix. Figure 8 provides the structure of the deverbal noun with verbal extensions. 


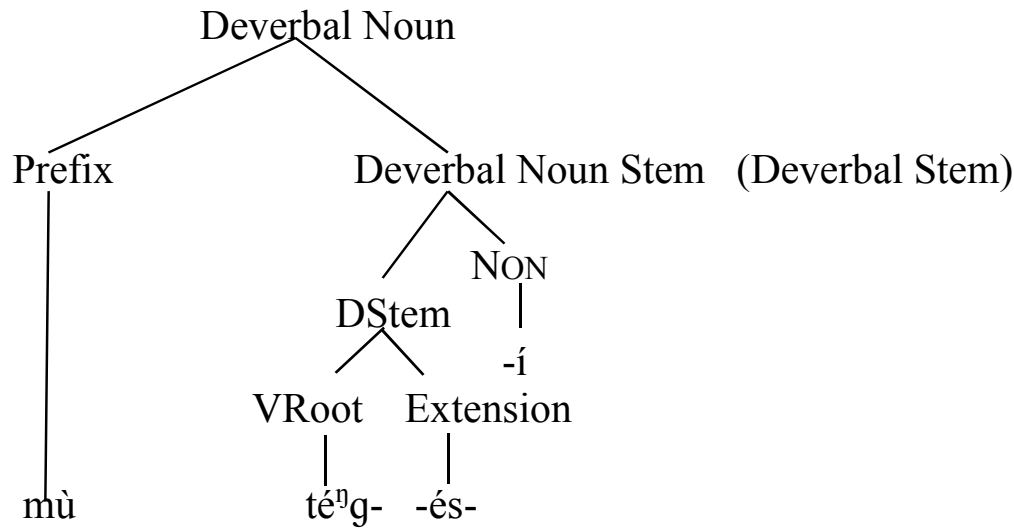

Figure 8. Deverbal noun with a verbal extension

In Figures 9a and $\mathrm{b}$, we provide a juxtaposed structure of a deverbal noun and that of the nondeverbal noun to illustrate the differences in morphological complexity amongst these nouns.

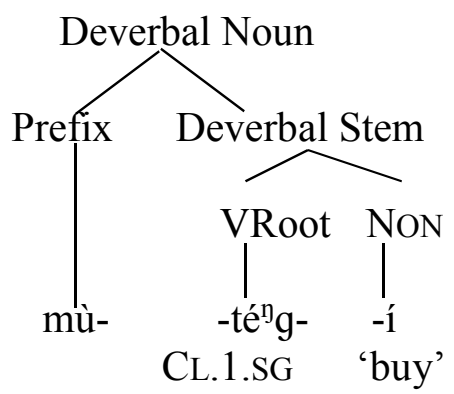

Figure 9a. Deverbal noun

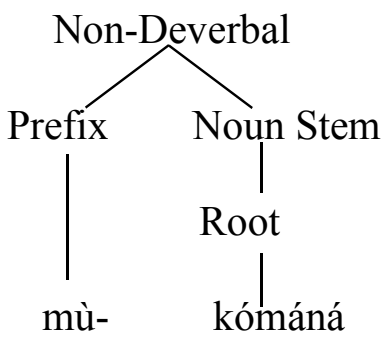

Figure 9b. Non-deverbal noun

\subsection{Deverbal and non-deverbal boundary differences: Hiatus resolution as a diagnostic tool}

In many Bantu languages, hiatus - a heterosyllabic sequencing of adjacent vowels - is a dispreferred configuration (see, for example, Casali 1997, 1998, 2011). What is marked is not the vowel hiatus $\left(\mathrm{V}_{1} \cdot \mathrm{V}_{2}\right.$ sequence) per se but the fact that in this configuration $\mathrm{V}_{2}$ occurs as an onsetless syllable. Onsetless syllables are marked and for this reason they are banned in many languages of the world (Ito 1989; Casali 1997, 1998; Prince and Smolensky 2004:4). In Optimality Theory (OT) terms, onsetless syllables violate the markedness constraint ONSET, which demands that syllables begin with consonants (Ito 1989, Prince and Smolensky 2004). What triggers hiatus resolution is the desire to "repair" the onsetless syllable.

Mudzingwa (2010) persuasively argues that in Shona, hiatus resolution strategies are sensitive to morphosyntatic boundaries. Mudzingwa (2010), for example, demonstrates that hiatus is never tolerated in Shona and is repaired without exception. This means that at morpheme boundaries where hiatus occurs, hiatus is repaired and all surface forms have CV syllables. Mudzingwa (2010) identifies and analyses five hiatus resolution strategies in Shona, namely glide formation, secondary articulation, elision, coalescence and spreading. Mudzingwa (2010, 2013) and Mudzingwa and Kadenge $(2011,2013)$ demonstrate that in Shona glide formation, secondary articulation and elision occur across a root boundary, and spreading across a verbal 
stem boundary. On the issue of hiatus resolution across a class prefix and noun stem boundary, Fortune (1955:60) observes that

before non-deverbative stems commencing in a vowel, the prefix $m u \rightarrow m \eta-$, the vowel $u$ being consonantalised; dialectically, however, semi-consonantalization $(m w-)$ and semi-consonantalization with nasal resonance $(m \tilde{w}-)$ is in place of full consonantalization. The prefix $v a \rightarrow v$-, the vowel $a$ being elided. This does not happen before deverbative stems commencing in a vowel [...]

In the non-deverbal nouns in (24) and (25) below, hiatus is resolved through secondary articulation while in (26) and (27) it is resolved through elision. It is common crosslinguistically for high vowels to glide and for low vowels, especially /a/, to delete (see, for example, Rosenthall 1997; Casali 1997, 1998, 2011; Kadenge 2010; Mudzingwa 2013; Mudzingwa and Kadenge 2011; Simango and Kadenge 2014).

\section{Secondary articulation}

$$
\text { /mù-ánà/ }
$$
'child'

/mù-énì/

CL1.SG-visitor

[ménì

'visitor'

\section{Elision}

/và-àná/

[vàná]

'children'

[mª́nà]

/và-énì/

CL2.PL-visitor

'visitors'

In examples (28) through (31), we present deverbal nouns in which vocalic hiatus is resolved through spreading. In spreading, all the features of the epenthesised segment are supplied by an input segment. In Shona, [j] is used in the context of a coronal $\mathrm{V}_{2}[\mathrm{i}]$ or [e] and [w] in the context of labial $\mathrm{V}_{2}[\mathrm{u}]$ or $[\mathrm{o}]$. The glides, which are in complementary distribution and function as onsets for $\mathrm{V}_{2}$, are products of $\mathrm{V}$-Place spreading. Spreading eliminates onsetless syllables wordinitially, as shown in examples (28) and (30), and word-medially, as shown in examples (29), (31), (32) and (33). Curly brackets $(\{\})$ enclose prosodic stems.
(28) /ìt-ál
[jìtà]
$[\{$ jìtà $\}]$
do- FV
'do!' 
(29)

/mù-ìt-ì/

2PL-do- NoM

[mùjìti $] \quad[$ mù $\{j i t i ̀\}] \quad *\left[\mathrm{~m}^{\mathrm{w}} \mathbf{i t i}\right]$

'doers'

(30)

/ér-á/

weigh-Fv

'weigh!'

(31) /mù-ér-í/

CL1.SG-weigh-Nom

'the one who weighs'

/mù-ím b-í/

CL1.SG-sing-NOM

'singer'

/và-óngórór-í/

CL2.PL-spy-Nom

'spies'

[mùjérí $\quad[$ mù $\{j e ́ r i ́\}] \quad *\left[\mathrm{~m}^{\mathrm{w}}\right.$ érí $]$

[jérá $\quad[$ jérá $\}]$

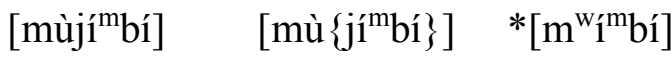

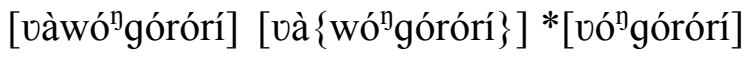

In examples (24) through (33), we have illustrated that the Shona deverbal and non-deverbal nouns have an asymmetrical morphophonology. In deverbal nouns, like in verbs, hiatus is resolved through spreading while in non-deverbal nouns hiatus is exclusively resolved through secondary articulation and elision. Based on the differences in hiatus resolution strategies employed, we conclude that the boundaries between a noun class prefix and a deverbal noun stem, and those between a noun class and a non-deverbal stem, are different.

\subsection{Diminutives}

There are two ways of forming diminutives in Shona, namely substitution and pre-prefixation (Fortune 1955). Substitution involves replacing the class prefix of the inherent noun class with the noun class prefix of the diminutive noun class; pre-prefixation, on the other hand, involves the stacking of prefixes where the diminutive class prefix is attached to the fully formed noun. (Recall that a fully formed noun is made up of a noun class prefix + stem.) Non-deverbal nouns and deverbal nouns show differences with respect to the formation of diminutives. Nondeverbal nouns employ the substitution strategy, similar to the singular-plural contrast. The class 1 prefix /mù-/ is replaced by the class prefix of the diminutive class. In contrast, deverbal nouns employ pre-prefixation. As illustration, the class 1 prefix /mù-/ is retained and the diminutive class is added to a fully inflected noun that contains a class prefix. Examples (34) through (36) show diminutive formation in non-deverbal nouns. 
Non-deverbal nouns

(34)

$$
\begin{aligned}
& \text { /mù-kómánál } \\
& \text { CL1.SG-boy } \\
& \text { 'boys' }
\end{aligned}
$$

\begin{tabular}{|c|c|}
\hline $\begin{array}{l}{[\text { kà-kómáná] }} \\
\text { Cl12.SG-boy } \\
\text { 'small boy' }\end{array}$ & *[kàmùkómáná] \\
\hline $\begin{array}{l}\text { [kà-síkáná] } \\
\text { CL12.SG-girl } \\
\text { 'small girl' }\end{array}$ & *[kàmùsíkáná] \\
\hline $\begin{array}{l}\text { [kà-kádzi] } \\
\text { CL12.SG-woman } \\
\text { 'small woman' }\end{array}$ & *[kà-mù-kádzi] \\
\hline
\end{tabular}

\section{Diminutive}

As shown above, diminutive formation in non-deverbal nouns involves the substitution of the class 1 prefix with the diminutive class prefix. In contrast, diminutives of deverbal nouns are formed by simply adding the diminutive noun class prefix to the noun which already has a class prefix. This is shown in the examples below.

/mù-bát-íl

CL1.SG-hold-NoN

'the one who holds /the captors'

\author{
/kà-mù-bát-w-ál \\ CL12.SG-hold-PASSIVE-NON \\ 'the captive'
}

/kà-mù-bát-ís-w-íl

CL12.PL-Cl1.SG.-hold-CAUS-PASS-NON

'the one who was made/caused to be caught' [kà-mù-6át-i]

CL1.SG.CL1.SG.-hold-NoN

*[kàbátí

'the small one who holds /the small captors'

[kà-mù-6át-w-á]

*[kà6átwá]

CL12.SG.CL1.SG.-hold-PASSIVE-NON

'the small captive'

[kà-mù-6át-ís-w-i]

*[kàbátíswi]

CL12.SG.CL1.SG.-hold-CAUS-PASS-NON

'the small one who was made/caused to be caught'

With deverbal nouns, substitution of the class 1 prefixes with the diminutive prefixes is unacceptable in the language. The fact that it is not possible to add the diminutive prefix to the deverbal stem of a deverbal noun suggests two things: first, the deverbal stem does not have semantic content similar to that of the non-deverbal nouns. By this, we mean that the stem /komanal, for instance, carries the meaning of 'boy'. A class prefix acts as a "modifier", telling us more about the 'boy', i.e. whether it is singular, plural, big (augmentative), small (diminutives) or pejorative. In addition to classifying the noun, the prefix qualifies the stem as it provides other additional semantic and descriptive information. Different class prefixes add different semantic and descriptive information to the noun.

Similarly, when diminutives modify a fully formed noun, they are playing a dual role classifying the noun and qualifying the noun by giving additional information such as size or whether or not it is pejorative (see Déchaine, Girard, Mudzingwa and Wiltschko 2014). Out of context or in isolation, the two nouns mukomana ('boy') and kakomana ('small, thin boy') are different in that the former is the "normal", "neutral" or the expected specimen, with respect to all entities of that particular kind, whereas the latter is not. kakomana is smaller, smaller than expected or smaller compared to the normal specimen. It needs modification for us to know 
whether it is neutral or diminutive. Once the class prefix is added, the type of specimen being referred to becomes clear.

\subsection{Class 21}

All nouns that fall into class 21 are fully formed nouns that function and are further inflected with a second noun class prefix. This means that class 21 takes fully inflected nouns to form augmentatives. Marconnes (1931:51), for example, says that /zi-/ "is the magnifying article [and the] greatness it denotes is generally only relative to other objects of the same kind". This suggests that /zi-/ can only take a fully formed noun, that is, a referring expression with a referent. Crystal (1991:293) defines a "referent" as "[...] the entity (object, state of affairs, etc.) in the external world to which a linguistic expression relates". The linguistic expression, in turn, has to be one that has a referent, such as nouns, noun phrases and adjectives; roots, stems, affixes that do not have referents cannot be considered linguistic expressions. Following this logic, this means that, in our case, the class 21 prefix /zi-/, which takes linguistic expressions that have referents, takes fully inflected nouns and produces a complex noun which has a new referent. The semantics mirrors what happens in the morphology. /zi-/ takes a noun and forms a complex noun that has stacked prefixes. In Shona deverbal nouns, the class 21 augmentative is formed by adding the /zi-/ prefix to an inflected noun, as shown in examples (40) and (41) below.

[mu6áti]
CL.1.-hold/touch-NON
'hold/touch'
[zimùbátwá]
CL21.-CL.1.SG-hold-PASS-NON
'the big captive'

[zimùbáti]

CL21.SG-CL1.SG-hold-NON

*[zibáti]

'the big one who holds /the big captor' 'the big captive'

[zimù $b a ́ t i ́ s w i]$

CL21.SG-CL1.SG.-hold-CAUS-PASS-NON

'the big one who was made/caused to be caught'

Class 1 nouns with voiceless stem-initial consonants are augmented in class 5 by voicing these stem-initial consonants. Fortune (1955:104) notes that "[a]ugmentatives of second degree may be formed by preprefixing class 21 prefix to these augmentatives". However, unlike deverbal nouns, non-deverbal nouns do not retain the class 1 prefix /mu-/ in class 21 forms.

/zi-mu-kadzi/

[zigadzi]

*[zimukadzi]

CL21.SG.-CL1.SG.-woman

'large woman'

/zi-mu-komana/
CL21.SG.-CL1.SG.-boy
'large boy'

[zigomana]

*[zimukomana]

\footnotetext{
/zi-mu-sikana/

CL21.SG.-CL1.SG.-girl

'large or fat girl'
}

[ziḍzikana]

*[zimusikana] 


\subsection{Singular-plural contrast}

A common feature of Bantu languages is the singular-plural contrast. Nouns that are in the singular in one class tend to fall into the next or following class to form the plural. Nouns in class 1 are singular and when they are pluralised, they fall into class 2 . This is achieved by substituting the singular class prefix /mù-/ with the plural morpheme of class 2, viz. /và/. Despite the other differences highlighted above, the singular-plural formation process is the same in non-deverbal and deverbal nouns. Examples (45) through (47) show non-deverbal nouns and (48) through (50) deverbal nouns.

Singular-plural contrast in non-deverbal nouns

/mù-kómánál [mùkómáná] vs.
CL1.SG-boy
'boy'
/và-kómánál
CL2.Pl-boy
'boys'

(46)

\begin{tabular}{|c|c|c|c|}
\hline $\begin{array}{l}\text { /mù-sikánál } \\
\text { CL1.SG-girl } \\
\text { 'girl' }\end{array}$ & [mùsikáná] & vs. & $\begin{array}{l}\text { /và-síkánál } \\
\text { CL2.PL-girl } \\
\text { 'girls' }\end{array}$ \\
\hline
\end{tabular}

\begin{tabular}{|c|c|c|}
\hline $\begin{array}{l}\text { /mù-kádzíl } \\
\text { CL1.SG-woman } \\
\text { 'woman' }\end{array}$ & [mùkádzi] & vs. \\
\hline
\end{tabular}

[vàkádzi]

[vàsíkáná]

[vàkómáná]

'woman'

Singular-plural contrast in deverbal nouns

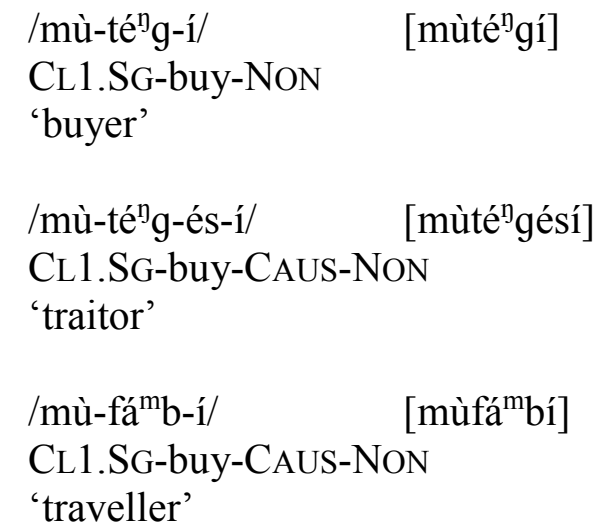

vs.

Deverbal nouns become nouns after the addition of the noun class prefix. In other words, nominalisation only becomes complete with the noun class prefix. Here, the noun class prefix plays a dual role: just like in the singular, it marks plurality (and controls agreement) and completes the nominalisation process.

\section{Conclusion}

This article presented a comparative analysis of the morphophological properties of deverbal and non-deverbal nouns in Shona noun class 1. Our main findings show that the stem of nondeverbal nouns is monomorphemic while that of deverbal nouns is intrinsically bimorphemic. We have demonstrated that vocalic hiatus resolution is a useful diagnostic tool in demonstrating 
the differences between non-deverbal and deverbal nouns. In non-deverbal nouns, like in other nominals in Shona grammar, hiatus is resolved via secondary articulation and elision, while in deverbal nouns, like in verbs, it is resolved through spreading. In forming diminutives, it has been shown that non-deverbal nouns utilise a substitution strategy where a noun class prefix of one class is substituted with that of the augmentative class; in deverbal nouns, however, prefix stacking is the strategy used to form the diminutive. The analytical machinery of any theory of nominal morphology needs to be rich enough to account for the sensitivity of word formation mechanisms to this non-uniformity in Bantu languages. This study contributes to a deeper understanding of Bantu nouns in general, and Shona nouns in particular. The surface similarities amongst nouns, even nouns that belong in the same class, belie significant diversity that requires deeper scrutiny in order to obtain a deeper understanding of the noun class system.

\section{Abbreviations and symbols used in this article}

$\begin{array}{ll}\text { AUG } & \text { augmentative } \\ \text { CAUS } & \text { causative } \\ \text { C } & \text { consonant } \\ \text { CL } & \text { noun class } \\ \text { CV } & \text { consonant vowel (syllable) } \\ \text { DIMIN } & \text { diminutive } \\ \text { DStem } & \text { Derived stem } \\ \text { FV } & \text { final vowel } \\ \text { IFS } & \text { Inflectional Final Suffix } \\ \text { INTERROG } & \text { Interrogative } \\ \text { IVStem } & \text { Inflected Verb Stem } \\ \text { LOC } & \text { locative } \\ \text { NEG } & \text { negative } \\ \text { NON } & \text { nominaliser } \\ \text { OM } & \text { Object marker } \\ \text { PASS } & \text { passive } \\ \text { PL } & \text { plural } \\ \text { SG } & \text { singular } \\ \text { SM } & \text { subject marker } \\ \text { SUBJ } & \text { subjunctive } \\ \text { TNS } & \text { tense } \\ \text { V } & \text { vowel } \\ \text { VRoot } & \text { Verb Root } \\ / / & \text { underlying representation (base form) } \\ {[]} & \text { surface representation } \\ \{\} & \text { prosodic stem } \\ \text { \& } & \text { syllable break } \\ \varnothing & \text { zero prefix } \\ . & \text { breathy voiced } \\ \end{array}$




\section{References}

Bleek, W.H.I. 1862. A comparative grammar of South African languages. London: Trubner \& Co.

Casali, R.F. 1997. Vowel elision in hiatus contexts: Which vowel goes? Language 73: 493-533.

Casali, R.F. 1998. Resolving hiatus. New York: Garland.

Casali, R.F. 2011. Hiatus resolution. In M. Van Oostendorp, C.J. Ewen, E. Hume and K. Rice (eds.) The Blackwell companion to phonology. Malden, MA: Wiley Blackwell Publishers. pp. 1434-1460.

Crystal, D. 1991. A dictionary of linguistics and phonetics. Malden, MA and Oxford: Blackwell Publishers.

Déchaine, R.-M., R. Girard, C. Mudzingwa and M. Wiltschko. 2014. The internal syntax of Shona class prefixes. Language Sciences 43: 18-46.

Downing, L.J. 1998. On the prosodic misalignment of onsetless syllables. Natural Language \& Linguistic Theory 16(1): 1-52.

Downing, L.J. 2000. Morphological and prosodic constraints on Kinande verbal reduplications. Phonology 17(1): 1-38.

Downing, L.J. 2005. Morphology conditions minimality in Bantu languages. In K. Bostoen and J. Maniacky (eds.) Studies in African comparative linguistics, with special focus on Bantu and Mande. Tervuren: MRCA. pp. 259-280.

Downing, L.J. 2006. Canonical forms in prosodic morphology. Oxford: Oxford University Press.

Fortune, G. 1955. An analytical grammar of Shona. Longman: London.

Fortune, G. 1984. Shona grammatical constructions. Harare: Mercury Press.

Guthrie, M. 1948. The classification of Bantu languages. London: Oxford University Press.

Hyman, L. 1993. Conceptual issues in the comparative study of the Bantu verb stem. In S.S. Mufwene and L. Moshi (eds.) Topics in African linguistics. Amsterdam: John Benjamins. pp. 3-34.

Hyman, L. 2005. Directional asymmetries in the morphology and phonology of words, with special reference to Bantu. Available online: http://linguistics.berkeley.edu/ hyman/Hyman Leipzig_word_Linguistics.pdf (Accessed 31 October 2014).

Ito, J. 1989. A prosodic theory of epenthesis. Natural Language \& Linguistic Theory 7(2): 217-259.

Jefferies, A. 2000. This is this, and here are some examples: Verbalisers and extensions in Shona. ZAMBEZIA: Journal of Humanities of the University of Zimbabwe 27(1): 1-26.

Kadenge, M. 2010. Hiatus contexts and hiatus resolution strategies in Zezuru. Southern African Linguistics and Applied Language Studies 28(1): 1-11. 
Keach, C.N.B. 1986. Word-internal evidence from Swahili for Aux/INFL. Linguistic Inquiry 17: 559-564.

Marconnes, F.A. 1931. A grammar of central Karanga: The language of old Monomotapa as at present spoken in central Mashonaland, Southern Rhodesia. Johannesburg: Witwatersrand University Press.

Meeussen, A.E. 1967. Bantu grammatical reconstructions. Annales du Musée Royal de l'Afrique Centrale 8(61): 81-121.

Meinhof, C. 1932. Principles of the comparative grammar of the Bantu languages. Berlin: Reimer.

Mkanganwi, K.G. 1995. Shona: A grammatical sketch. Unpublished manuscript, University of Zimbabwe.

Mkanganwi, K.G. 2002. Shona (derivational) morphology: An observation in search of a theory. ZAMBEZIA: Journal of Humanities of the University of Zimbabwe 29(2): 174-190.

Mudzingwa, C. 2010. Shona Morphophonemics: Repair Strategies in Karanga and Zezuru. Unpublished PhD thesis, University of British Columbia.

Mudzingwa, C. 2013. Hiatus resolution strategies in Karanga (Shona). South African Linguistics and Applied Language Studies 33(1): 1-24.

Mudzingwa, C. and M. Kadenge. 2011. Comparing hiatus resolution in Karanga and Nambya: An Optimality Theory account. Nordic Journal of African Studies 20(3): 203-240.

Mudzingwa, C. and M. Kadenge. 2013. An analysis of the ghost augment in Shona. South African Journal of African Languages 33(1): 87-94.

Mugane, J.M. 1997. A paradigmatic grammar of Gikuyu. Stanford: CSLI Publications.

Mutaka, N. and L. Hyman. 1990. Syllables and morpheme integrity in Kinande reduplication. Phonology 7: 73-119.

Myers, S. 1990. Tone and the structure of words in Shona. New York: Garland.

Ngunga, A. 2000. Phonology and morphology of Ciyao verb. Stanford: CSLI Publications.

Prince, A. and P. Smolensky, 2004. Optimality Theory: Constraint interaction in generative grammar. Malden, MA: Blackwell.

Rosenthall, S. 1997. The distribution of prevocalic vowels. Natural Language \& Linguistic Theory 15(1): 139-180.

Simango, S.R. and M. Kadenge. 2014. Vowel hiatus resolution in ciNsenga: An Optimality Theory analysis. Southern African Linguistics and Applied Language Studies 32(1): 79-96. 